\title{
Sugar and NICE - Aggressive Hyperglycaemic Control in Ischaemic Stroke and What Can We Learn from Non-Neurological Intensive Glucose Control Trials in the Critically III?
}

\author{
Stefan H. Kreisel ${ }^{\mathrm{a}, \mathrm{b}}$ Angelika Alonso ${ }^{\mathrm{a}}$ Kristina Szabo ${ }^{\mathrm{a}}$ Michael G. Hennerici ${ }^{\mathrm{a}}$ \\ a Department of Neurology, Universitätsklinikum Mannheim, University of Heidelberg, Mannheim, and \\ ${ }^{b}$ Deparment of Psychiatry and Psychotherapy Bethel, Evangelisches Krankenhaus Bielefeld, Bielefeld, Germany
}

Hyperglycaemia is a common phenomenon after cerebral ischaemia (for that matter, after most acute medical or surgical conditions), and clinicians have certainly been itching to treat. But should we? The devil is in the details.

Continuous assessment of blood glucose levels and qualified treatment are often noted to be core components of specialized stroke care [1]. Expert statements have taken a somewhat sinusoidal course when discussing the matter. In 1994, the Stroke Council of the American Heart Association said that it may be a good idea to treat hyperglycaemia in patients with stroke just as one would treat hyperglycaemia in 'other persons with elevated blood glucose' [2]. The guideline was substantiated in 2003, with treatment then being warranted should blood glucose levels exceed $16.6 \mathrm{mmol} / \mathrm{l}(300 \mathrm{mg} / \mathrm{dl})$ [3]. Europeans were more stringent, finding that a cut-off of 10 $\mathrm{mmol} / \mathrm{l}(180 \mathrm{mg} / \mathrm{dl})$ would be optimal $[4,5]$. The American Stroke Association followed this lead and in 2007 revised its suggestions and noted that treatment should begin above $11.1 \mathrm{mmol} / \mathrm{l}(200 \mathrm{mg} / \mathrm{dl})$, possibly as low as 7.8 $\mathrm{mmol} / \mathrm{l}(140 \mathrm{mg} / \mathrm{dl})$ [6]. In 2008, instead of continuing on the downward track and effectively postulating fasting normoglycaemia below $5.5 \mathrm{mmol} / \mathrm{l}(99 \mathrm{mg} / \mathrm{dl})$, the European Stroke Organization retained its previous recommendation of $10 \mathrm{mmol} / \mathrm{l}(180 \mathrm{mg} / \mathrm{dl})$ [7].

\section{KARGER}

Fax +4161306 1234 E-Mail karger@karger.ch www.karger.com
(C) 2010 S. Karger AG, Basel

$1015-9770 / 10 / 0296-0518 \$ 26.00 / 0$

Accessible online at:

www.karger.com/ced
There are two lines of evidence that drove the evolution of these guidelines:

(1) The weight of arguments that suggest an association between high glucose levels and detrimental outcome has substantially increased in the last few years. Observational studies, both naturalistic $[8,9]$ and trialassociated [10-12], have reported higher morbidity and mortality in patients with initial hyperglycaemia. (Note that there is neither consensus as to what actually defines 'initial' - is it a 1-measurement baseline, continuously elevated levels within the first $24 \mathrm{~h}$ or other timelines? - nor is there a clear definition of when hyperglycaemia necessitates treatment [13].) Moreover, experimental data have underlined the association. Early neuropathological animal studies provided evidence that hyperglycaemia augments morphological brain damage in acute stroke [14, 15]. Imaging studies in hyperglycaemic animals subjected to ischaemic stroke corroborated these findings: hyperglycaemia is associated with enhanced MRI diffusion-weighted imaging alterations [16] and reduced hemispheric cerebral blood volume [17]. Importantly, equivalent correlations have been established in MRI studies in human subjects. Acute hyperglycaemia is associated with reduced salvage of perfusion-impaired tissue and larger final infarct size $[18,19]$. This is also true for patients treated with intravenous tissue plasminogen

E-Mail skreisel@neuro.ma.uni-heidelberg.de 
activator, where acute hyperglycaemia is further correlated with lower recanalization rates [20-22]. But is association really causality? Hyperglycaemia has been related to the size of the ischaemic lesion, stroke location, age and prior as well as unrecognized diabetes, among other variables [23-25]. There remains considerable controversy over whether hyperglycaemia as such is a truly independent predictor of detrimental effects or just plays a role as a prominent confounder or effect mediator [26].

(2) If one accepts a causal pathway, then (and only then) does it seem truly promising to treat hyperglycaemia. Undoubtedly, the development of the consensus guidelines was influenced by the very encouraging results from large non-neurological critical-care trials. Though the pathophysiology of specific end-organ damage due to hyperglycaemia in ischaemic stroke may be different to that expected in non-neurological cohorts [for a review, see 26-28], there is also clear overlap, paradoxically often scotomized in the literature: both populations are acutely and seriously ill, and share many complications contributing to higher morbidity and mortality. The first large randomized controlled trial addressing the question whether aggressive glucose normalization may be beneficial was performed in Leuven, Belgium, in $2001(\mathrm{n}=1,548)[29]$ - it was to become highly influential. Patients having undergone cardiac surgery and other surgical procedures were either treated with an intravenous insulin regimen, targeting $4.4-6.1 \mathrm{mmol} / \mathrm{l}(80-110 \mathrm{mg} /$ dl) or were treated only when blood glucose concentrations exceeded the renal threshold (i.e. $12 \mathrm{mmol} / \mathrm{l}$ or 215 $\mathrm{mg} / \mathrm{dl}$ ). The authors showed an absolute risk reduction in in-hospital mortality of $3.4 \%$ favouring treatment. Though a subsequent trial by the same study group, now also involving patients with serious medical conditions, missed significance in respect to mortality (overall morbidity was however reduced, especially in those having undergone longer periods of intervention), such a momentum was now there that many commentators were led to conclude that normoglycaemia should be a goal in the care of critically ill patients independently of anything else; those involved in the care of stroke patients were quick to follow $[27,30]$.

Recently Terence Quinn and Kennedy Lees thoroughly reviewed the 'but should we' question whether or not to treat hyperglycaemia in patients with ischaemic stroke in this journal [28]. They highlighted that though research has been intensified in recent years, there is little evidence that supports pro-active treatment, much less aggressive intervention resulting in normal fasting blood glucose concentrations. The only large-scale prospective randomized trial to date (i.e. GIST-UK; $\mathrm{n}=933$ ) produced neutral results. The active normalization $(4-7 \mathrm{mmol} / \mathrm{l}$ or $72-126 \mathrm{mg} / \mathrm{dl}$ ) of blood glucose using glucose-potassiuminsulin infusions (GKI) failed to reduce mortality at 90 days or ameliorate neurological outcome. Smaller studies, using different treatment regimens (there are numerous treatment modalities and algorithms of varying complexity suitable for glycaemic control: GKI, subcutaneous sliding scale schemes, varying intravenous insulin infusion protocols, with or without concomitant glucose administration), have also remained neutral as to the treatment goals studied (i.e. mortality, neurological outcome) [31-35]. The GIST-UK, besides not having reached the intended study size due to slow recruitment, may have 'failed' because the GKI regimen insufficiently lowered blood glucose concentrations (i.e. $0.57 \mathrm{mmol} / \mathrm{l}$ or 10.3 $\mathrm{mg} / \mathrm{dl}$ ) - Quinn and Lees conclude that 'to achieve meaningful clinical improvements, glucose change must be substantial ...' [28]. Intravenous insulin infusion protocols may in fact have a higher efficacy $[31,33,35]$ and were successful in non-neurological trials, as noted above [29].

The GIST-UK had further potential shortcomings: The treatment duration was short (limited to $24 \mathrm{~h}$ ), much shorter than in the medical and surgical study settings [36]; there is some evidence that glucose dysregulation persists after the first day following the onset of ischaemia and may be detrimental in the long run $[11,35]$. Furthermore, study initiation was well after stroke onset (i.e. median 'time-to-needle' was $14 \mathrm{~h}$ ), potentially missing the time window of the most effective treatment.

So were we stroke folks doing it all wrong? Well, maybe not. In the meantime, the results of the largest study to date (NICE-SUGAR study; $\mathrm{n}=6,104$ ), a multi-centre trial testing the effect of an intravenous insulin regimen, lowering blood glucose concentrations to the range of 4.5-6 mmol/l (81-108 $\mathrm{mg} / \mathrm{dl})$, versus an approach with target values of $8-10 \mathrm{mmol} / \mathrm{l}(144-180 \mathrm{mg} / \mathrm{dl})$ in a nonneurological mixed acutely ill population (approx. one third surgical patients), have been published [37]. Though not completely unexpected, they were sobering: intervention actually increased the absolute risk of mortality by $2.6 \%$. Though there are methodological differences between the Leuven and the NICE-SUGAR studies, and possible confounders may play a significant role in the latter trial [38], the results do lend serious support to commentators that have questioned the benefit of aggressive therapy in critically ill patients $[39,40]$.

Do the results of this trial, powerful as they are, effectively end attempts to 'significantly' treat hyperglycaemia 
in the critically ill - including stroke patients? The devil is in the details:

- While there is now much rumination in the criticalcare community as to 'what went wrong', a possible 'compromise' may be evolving, with reverberations also for patients with cerebral ischaemia: clearly at odds with previous thinking, clinical improvement may not depend on substantial glucose change; rather lower blood glucose levels, but not necessarily normoglycaemia, could be the optimal target. In fact in the Leuven trials, three quarters of the mortality reduction were accounted for by patients reaching a range of $6.1-8.3 \mathrm{mmol} / \mathrm{l}(110-150 \mathrm{mg} / \mathrm{dl})$, but not lower; the NICE-SUGAR results effectively reflect benefit in this range (the mean concentration of the control group was $7.9 \mathrm{mmol} / \mathrm{l}$ or $142 \mathrm{mg} / \mathrm{dl}$, with almost $70 \%$ of this arm actually having received insulin during the course of the study). There is also some indication that a mid-range glucose concentration (i.e. $8.6 \mathrm{mmol} / \mathrm{l}$ or 155 $\mathrm{mg} / \mathrm{dl}$ ) may represent a watershed in stroke patients, with outcomes of those lying below this value being better [41] It must, however, be fairly said that no studies to date have tested interventions leading to intermediate glucose levels versus the conventional approach of 'wait and see', treating only when concentrations surpass the renal threshold.

Other considerations also seem relevant:

- Though diabetics have been routinely included in these trials (both stroke and other critical-care cohorts), they may in fact not benefit from stricter glycaemic control [36]. Diabetics are potentially adapted to higher blood glucose concentrations, and they do show a significantly lower mortality at higher glycaemic levels in the acute setting than non-diabetics, both in ischaemic stroke [8] and in other critical illnesses [42, 43]. Patients with non-diabetic hyperglycaemia, alternatively coined reactive [44] or stress [8] or non-diabetic post-stroke hyperglycaemia [28], may be the more suitable treatment target.

- Feeding strategies could play a pivotal role in light of high insulin load. Though there is no consensus as to when and how to initiate feeding, in the successful Leuven trial, insufficient enteral feeding was supplemented by a parenteral regimen, guaranteeing sufficient calories; the NICE-SUGAR trial relied solely on enteral feeding, effectively being hypocaloric. In the stroke setting, things become even more complicated; due to lack of specific trials that investigate the effect of different caloric regimens commencing very close to onset, there is evidence that enteral tube feeding starting within a couple of days reduces mortality versus avoiding tube feeding [45]. Moreover, under intensive insulin therapy, continuous tube feeding has been shown to increase the efficacy of glycaemic control and to reduce hypoglycaemic events [46].

- The stress on caregivers is enormous. Frequent measurements and adjustments can only be performed in a highly dedicated setting. Glucometers should be accurate and standardized; optimally automated continuous measurements should be preferred, once available.

There are also stroke-specific pathophysiological issues:

- Treatment should be commenced early on, preferably in the same time window as applicable for thrombolysis, targeting salvageable tissue [28], and sustained for longer periods of time (e.g. 3-5 days [35, 47]).

- Direct and indirect potential toxic effects of hyperglycaemia are more prominent in larger infarctions. Moreover, patients with lacunar stroke seem to profit from hyperglycaemia up to a concentration of $12 \mathrm{mmol} / \mathrm{l}$ (216 mg/dl) [48, 49].

But then should we treat hyperglycaemia in ischaemic stroke? The answer is yes and no, applicable to both future trials and the individual basis. We believe that treatment is warranted, targeting an intermediate range (6.7$8.3 \mathrm{mmol} / \mathrm{l}$ or $110-150 \mathrm{mg} / \mathrm{dl}$ ) in non-diabetic patients with non-lacunar stroke. We would advocate an immediate start of therapy, sustained for at least 3 days after onset, using an intravenous infusion protocol, but only if a highly dedicated monitoring and treatment infrastructure is available. Feeding should be started in parallel, enterally if possible, or otherwise parenterally, to guarantee sufficient calorie intake.
References
Cerebrovasc Dis 2010;29:518-522
1 Langhorne P, Pollock A: What are the components of effective stroke unit care? Age Ageing 2002;31:365-371.

-2 Adams HP Jr, Brott TG, Crowell RM, Furlan AJ, Gomez CR, Grotta J, Helgason CM, Marler JR, Woolson RF, Zivin JA, et al: Guidelines for the management of patients with acute ischemic stroke: a statement for healthcare professionals from a special writing group of the stroke council, American Heart Association. Circulation 1994;90:15881601.

- 3 Adams HP Jr, Adams RJ, Brott T, del Zoppo GJ, Furlan A, Goldstein LB, Grubb RL, Higashida R, Kidwell C, Kwiatkowski TG, Marler JR, Hademenos GJ: Guidelines for the early management of patients with ischemic stroke: a scientific statement from the stroke council of the American Stroke Association. Stroke 2003;34:1056-1083. 
$\checkmark 4$ European stroke initiative recommendations for stroke management. European Stroke Council, European Neurological Society and European Federation of Neurological Societies. Cerebrovasc Dis 2000;10:335351.

5 Olsen TS, Langhorne P, Diener HC, Hennerici $M$, Ferro J, Sivenius J, Wahlgren NG, Bath P: European stroke initiative recommendations for stroke management - update 2003. Cerebrovasc Dis 2003;16:311-337.

-6 Adams HP Jr, del Zoppo G, Alberts MJ, Bhatt DL, Brass L, Furlan A, Grubb RL, Higashida RT, Jauch EC, Kidwell C, Lyden PD, Morgenstern LB, Qureshi AI, Rosenwasser RH, Scott PA, Wijdicks EF: Guidelines for the early management of adults with ischemic stroke: a guideline from the American Heart Association/American Stroke Association stroke council, clinical cardiology council, cardiovascular radiology and intervention council, and the atherosclerotic peripheral vascular disease and quality of care outcomes in research interdisciplinary working groups: The American Academy of Neurology affirms the value of this guideline as an educational tool for neurologists. Stroke 2007;38: 1655-1711.

7 Guidelines for management of ischaemic stroke and transient ischaemic attack 2008. Cerebrovasc Dis 2008;25:457-507.

$\checkmark 8$ Capes SE, Hunt D, Malmberg K, Pathak P, Gerstein HC: Stress hyperglycemia and prognosis of stroke in nondiabetic and diabetic patients: a systematic overview. Stroke 2001;32:2426-2432.

9 Kostulas N, Markaki I, Cansu H, Masterman T, Kostulas V: Hyperglycaemia in acute ischaemic stroke is associated with an increased 5-year mortality. Age Ageing 2009;38:590594.

10 Bruno A, Levine SR, Frankel MR, Brott TG, Lin Y, Tilley BC, Lyden PD, Broderick JP, Kwiatkowski TG, Fineberg SE: Admission glucose level and clinical outcomes in the NINDS rt-PA stroke trial. Neurology 2002; 59:669-674.

11 Yong M, Kaste M: Dynamic of hyperglycemia as a predictor of stroke outcome in the ECASS-II trial. Stroke 2008;39:2749-2755.

-12 Poppe AY, Majumdar SR, Jeerakathil T, Ghali W, Buchan AM, Hill MD: Admission hyperglycemia predicts a worse outcome in stroke patients treated with intravenous thrombolysis. Diabetes Care 2009;32:617622.

13 Fuentes B, Diez-Tejedor E: General care in stroke: relevance of glycemia and blood pressure levels. Cerebrovasc Dis 2007;24(suppl 1):134-142.

- 14 Pulsinelli WA, Waldman S, Rawlinson D, Plum F: Moderate hyperglycemia augments ischemic brain damage: a neuropathologic study in the rat. Neurology 1982;32:12391246.
15 Yip PK, He YY, Hsu CY, Garg N, Marangos P, Hogan EL: Effect of plasma glucose on infarct size in focal cerebral ischemia-reperfusion. Neurology 1991;41:899-905.

16 Martin A, Rojas S, Chamorro A, Falcon C, Bargallo N, Planas AM: Why does acute hyperglycemia worsen the outcome of transient focal cerebral ischemia? Role of corticosteroids, inflammation, and protein $o$-glycosylation. Stroke 2006;37:1288-1295.

17 Quast MJ, Wei J, Huang NC, Brunder DG, Sell SL, Gonzalez JM, Hillman GR, Kent TA: Perfusion deficit parallels exacerbation of cerebral ischemia/reperfusion injury in hyperglycemic rats. J Cereb Blood Flow Metab 1997; 17:553-559.

18 Parsons MW, Barber PA, Desmond PM, Baird TA, Darby DG, Byrnes G, Tress BM, Davis SM: Acute hyperglycemia adversely affects stroke outcome: a magnetic resonance imaging and spectroscopy study. Ann Neurol 2002;52:20-28.

19 Baird TA, Parsons MW, Phanh T, Butcher KS, Desmond PM, Tress BM, Colman PG, Chambers BR, Davis SM: Persistent poststroke hyperglycemia is independently associated with infarct expansion and worse clinical outcome. Stroke 2003;34:22082214.

20 Ribo M, Molina C, Montaner J, Rubiera M, Delgado-Mederos R, Arenillas JF, Quintana M, Alvarez-Sabin J: Acute hyperglycemia state is associated with lower tPA-induced recanalization rates in stroke patients. Stroke 2005;36:1705-1709.

21 Alvarez-Sabin J, Molina CA, Ribo M, Arenillas JF, Montaner J, Huertas R, Santamarina E, Rubiera M: Impact of admission hyperglycemia on stroke outcome after thrombolysis: risk stratification in relation to time to reperfusion. Stroke 2004;35:2493-2498.

22 Ribo M, Molina CA, Delgado P, Rubiera M, Delgado-Mederos R, Rovira A, Munuera J, Alvarez-Sabin J: Hyperglycemia during ischemia rapidly accelerates brain damage in stroke patients treated with tPA. J Cereb Blood Flow Metab 2007;27:1616-1622.

23 Christensen H, Boysen G: Blood glucose increases early after stroke onset: a study on serial measurements of blood glucose in acute stroke. Eur J Neurol 2002;9:297-301.

24 Allport LE, Butcher KS, Baird TA, MacGregor L, Desmond PM, Tress BM, Colman $\mathrm{P}$, Davis SM: Insular cortical ischemia is independently associated with acute stress hyperglycemia. Stroke 2004;35:1886-1891.

25 Gray CS, French JM, Bates D, Cartlidge NE, Venables GS, James OF: Increasing age, diabetes mellitus and recovery from stroke. Postgrad Med J 1989;65:720-724.

26 McCormick MT, Muir KW, Gray CS, Walters MR: Management of hyperglycemia in acute stroke: how, when, and for whom? Stroke 2008;39:2177-2185.
$>27$ Garg R, Chaudhuri A, Munschauer F, Dandona P: Hyperglycemia, insulin, and acute ischemic stroke: a mechanistic justification for a trial of insulin infusion therapy. Stroke 2006;37:267-273

28 Quinn TJ, Lees KR: Hyperglycaemia in acute stroke - to treat or not to treat. Cerebrovasc Dis 2009;27(suppl 1):148-155.

29 van den Berghe G, Wouters P, Weekers F, Verwaest C, Bruyninckx F, Schetz M, Vlasselaers D, Ferdinande P, Lauwers P, Bouillon $\mathrm{R}$ : Intensive insulin therapy in the critically ill patients. N Engl J Med 2001;345:13591367.

30 Roine RO, Lindsberg PJ: Editorial comment - prime time for proactive blood glucose control? Stroke 2004;35:2498-2499.

-31 Walters MR, Weir CJ, Lees KR: A randomised, controlled pilot study to investigate the potential benefit of intervention with insulin in hyperglycaemic acute ischaemic stroke patients. Cerebrovasc Dis 2006; 22:116-122.

32 Bruno A, Kent TA, Coull BM, Shankar RR, Saha C, Becker KJ, Kissela BM, Williams LS: Treatment of hyperglycemia in ischemic stroke (THIS): a randomized pilot trial. Stroke 2008;39:384-389.

33 Bruno A, Saha C, Williams LS, Shankar R: IV insulin during acute cerebral infarction in diabetic patients. Neurology 2004;62: 1441-1442.

-34 ScottJF, Robinson GM, FrenchJM,O'Connell JE, Alberti KG, Gray CS: Glucose potassium insulin infusions in the treatment of acute stroke patients with mild to moderate hyperglycemia: the Glucose Insulin in Stroke Trial (GIST). Stroke 1999;30:793-799.

>35 Kreisel SH, Berschin UM, Hammes HP, Leweling $\mathrm{H}$, Bertsch $\mathrm{T}$, Hennerici MG, Schwarz S: Pragmatic management of hyperglycaemia in acute ischaemic stroke: safety and feasibility of intensive intravenous insulin treatment. Cerebrovasc Dis 2009;27:167175.

-36 Van den Berghe G, Wilmer A, Milants I, Wouters PJ, Bouckaert B, Bruyninckx F, Bouillon R, Schetz M: Intensive insulin therapy in mixed medical/surgical intensive care units: benefit versus harm. Diabetes 2006;55: 3151-3159.

-37 Finfer S, Chittock DR, Su SY, Blair D, Foster D, Dhingra V, Bellomo R, Cook D, Dodek P, Henderson WR, Hebert PC, Heritier S, Heyland DK, McArthur C, McDonald E, Mitchell I, Myburgh JA, Norton R, Potter J, Robinson BG, Ronco JJ: Intensive versus conventional glucose control in critically ill patients. N Engl J Med 2009;360:1283-1297.

38 Van den Berghe G, Schetz M, Vlasselaers D, Hermans G, Wilmer A, Bouillon R, Mesotten D: Intensive insulin therapy in critically ill patients: Nice-Sugar or Leuven blood glucose target? J Clin Endocrinol Metab 2009; E-pub ahead of print. 
-39 Wiener RS, Wiener DC, Larson RJ: Benefits and risks of tight glucose control in critically ill adults: a meta-analysis. JAMA 2008;300: 933-944.

40 Finney SJ, Zekveld C, Elia A, Evans TW: Glucose control and mortality in critically ill patients. JAMA 2003;290:2041-2047.

41 Fuentes B, Castillo J, San Jose B, Leira R, Serena J, Vivancos J, Davalos A, Nunez AG, Egido J, Diez-Tejedor E: The prognostic value of capillary glucose levels in acute stroke: the Glycemia in Acute Stroke (GLIAS) study. Stroke 2009;40:562-568.

-42 Capes SE, Hunt D, Malmberg K, Gerstein HC: Stress hyperglycaemia and increased risk of death after myocardial infarction in patients with and without diabetes: a systematic overview. Lancet 2000;355:773-778.
43 Egi M, Bellomo R, Stachowski E, French CJ, Hart GK, Hegarty C, Bailey M: Blood glucose concentration and outcome of critical illness: the impact of diabetes. Crit Care Med 2008;36:2249-2255.

44 Melamed E: Reactive hyperglycaemia in patients with acute stroke. J Neurol Sci 1976;29: 267-275.

45 Dennis MS, Lewis SC, Warlow C: Effect of timing and method of enteral tube feeding for dysphagic stroke patients (FOOD): a multicentre randomised controlled trial. Lancet 2005;365:764-772.

46 Kruyt ND, Biessels GJ, Vriesendorp TM, Devries JH, Hoekstra JB, Elbers PW, Kappelle LJ, Portegies P, Vermeulen M, Roos YB: Subjecting acute ischemic stroke patients to continuous tube feeding and an intensive computerized protocol establishes tight glycemic control. Neurocrit Care 2009; E-pub ahead of print.
47 Allport L, Baird T, Butcher K, Macgregor L, Prosser J, Colman P, Davis S: Frequency and temporal profile of poststroke hyperglycemia using continuous glucose monitoring. Diabetes Care 2006;29:1839-1844.

48 Bruno A, Biller J, Adams HP Jr, Clarke WR, Woolson RF, Williams LS, Hansen MD: Acute blood glucose level and outcome from ischemic stroke. Trial of ORG 10172 in Acute Stroke Treatment (TOAST) investigators. Neurology 1999;52:280-284.

49 Uyttenboogaart M, Koch MW, Stewart RE, Vroomen PC, Luijckx GJ, De Keyser J: Moderate hyperglycaemia is associated with favourable outcome in acute lacunar stroke. Brain 2007;130:1626-1630. 